\title{
土木施工研究委員会の活動 \\ ACTIVITIES OF THE COMMITTEE ON CONSTRUCTION TECHNOLOGY
}

\author{
土木施工研究委員会 \\ The Committee on Construction Technology
}

\section{1. 土木施工研究委員会の目的}

土木学会の目的は, 土木工学の進歩および土木事業の 発達を図り，もって学術文化の進展に寄与することであ るが, 土木事業は, 研究・計画・調査・設計・施工の段 階を経て完成し，社会に奉仕するプロセスをたどる．

わが国の土木系新卒者の約半数が建設会社に就職して おり，土木技術者のうちで施工に携わる人々のウエイト が高いにもかかわらず，土木学会会員に占める比率は約 $20 \%$ 強に過ぎない (図一1 参照). その原因の一つは, 建設業で働く土木技術者がその活動に物足りなさを感じ るためと考えられる.この点から, 学会活動の質的変化 が求められている.

現在の施工技術は，かつての経験主体の時代から脱却 して, 高度の工学的な裏付けやコストダウン等の経営努

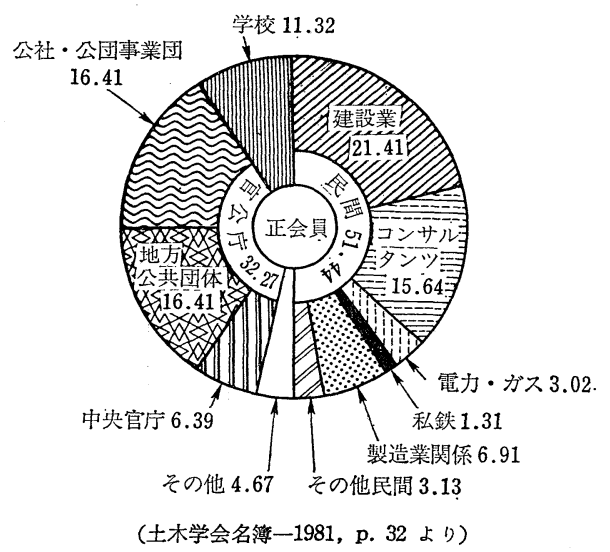

図一1 土木学会正会員の勤務先別内訳
カがなくては存在しえないものとなっている。さらに， 土木分野だけでなく業際分野に広がった幅広いエンジニ アリングが要求される.

さらに海外工事においては，わが国では遭遇しなかっ た新しい問題, 異なった仕様書, 契約方式等に対応する 必要がある.このような困難を克服しなければ，わが国 の土木分野の規模の拡大は望めないのが現状である.

一方, 学会に設置されている約 50 の委員会には施工 を専問とする技術者の立場から，施工に関する諸問題を 主として考える委員会は全く見当らない．以上の諸問題 について学会という立場で解決の途を検討すると共に， 施工技術者を対象とする学会事業計画の推進を図るため に, 土木施工研究委員会が設置された.

現在，建設業界は国内における建設投資の伸び㥗みに 伴い, 今後の発展方向として, プラント技術に代表され るようなエンジニアリングを含む EC 化，あるいは海外 進出の必要に応じてその体質の国際化などに真剣に取組 んでいるが, このパワーを委員会を通じて学会に反映す ることによって, その多くの未加入者の学会への入会と いらメリットも生まれ, 会員数の伸び悩みというより減

表一1 土木学会会員数の最近における変遷

\begin{tabular}{|c|c|c|c|c|}
\hline 年度 種別 & 正会員 ${ }^{1)}$ & 学生会員 & 特別会員 & 合 \\
\hline 昭和 50 年 3 月 & 22360 & 3832 & 985 & 27207 \\
\hline 昭和 52 年 3 月 & 21566 & 4017 & 1001 & 26584 \\
\hline 昭和 54 年 3 月 & 21603 & 4147 & 958 & 26708 \\
\hline 昭和56年 3 月 & 23433 & 2701 & 1002 & 27136 \\
\hline 昭和58年 3 月 & 23886 & 2022 & 1013 & 26921 \\
\hline 昭和 59 年 3 月 & 24276 & 1882 & $486^{2)}$ & 26644 \\
\hline 昭和 60 年 3 月 & 24450 & 1961 & $483^{2)}$ & 26894 \\
\hline
\end{tabular}

注 : 1）名誉会員を含む，昭和 59 年より特別会員の一部を含む. 2）正会員の制度の変更により，一部正会員に繰入れ。 
少の傾向の歯止めに役立つものと信じる (表一1 参照).

\section{2. 委員会設置の経緯}

昭和 58 年度土木学会理事会 (会長: 高橋浩二) では, 当 時の伊藤副会長らから土木学会の活性化をはかるべきで あるとの提案があり, 何回かの審議を経て昭和 58 年 8 月に企画委員会 (委員長 : 八十島義之助) の下に第 1 企画小委 員会 (委員長 : 高橋裕), 第 2 企画小委員会 (委員長：藤田圭一) を設けてその方策を探ることになった．これらの小委員 会に拉ける検討結果は, 報告書として企画委員会に昭和 59 年 5 月に提出され理事会に答申された. 数度にわた る検討を経て, 昭和 59 年 9 月の理事会 (会長: 岡部保) は, 企画委員会の答申の一つである「土木施工研究委員 会」の設置を決定し, 主として建設業界に属する技術者 のニーズに応えて施工分野を対象とする活動を行うこと になり, 昭和 59 年 10 月 30 日第 1 回委員会開催をもっ て発足した.

\section{3. 活動方針の検討}

企画第 2 小委員会の委員をそのまま本委員会の運営小 委員会 (委員長: 小林健郎, 蛙7 名) とし, まず大手の建設 業者に所属する技術者の土木学会に対するかかわりのほ か, 期待, 不満, 問題点などを調查したところ, 次のよ うなことが明らかになった。

(1) 学会に一度入ったが，退会した者が現会員数と ほぼ同じくらいいた。

(2) 学会に現在加入している人数は, 会員として入 会可能な人員数の約 1 割位である.

(3) 本社技術部門の学会加入率は, 現業部門より 遙 か涼い.

(4) 学会に加入している率は, 高年令層ほぼ高い.

(5) 高年令層は, 土木学会に対する期待度といらよ り，自ら専攻した職業に対する帰属意識といらょうな 面から入会している.

(6) 若年令層ほど現在の学会活動が異なった 次元に あると感じている。

(7) 学会との最大の接点となるべき学会誌の内容が 難しい.

(8) 土木学会より専門学会の活動のほうが親しみや すい.

以上のことを言いかえると，問題点は具体的に次のよう にまとめることができる.

i ) 学会に加入するメリットがない.

ii）学会の成果物として受取るものが難しすぎる.

iii）会費が高い，加入していなくても同じ情報が入
表一2 土木学会委員会一覧表 （1981 年現在）

\begin{tabular}{|c|c|c|}
\hline 1. 表 彰 & 19. 構造工学 & \\
\hline 2. 論文賞社 & . 海 & \\
\hline 3. 吉田賞選考 & 21. 耐震工学 & 36. 関門トンネル上部 \\
\hline 4. 田中賞選考 & 22. 原子力土木 & 航路浚深 \\
\hline 5. 定款調查 & 23. トンネル工学 & 37. 高校土木教育研究 \\
\hline 6. 企 画 & 24. 衛生工学 & 38. 大学土木教育 \\
\hline 7. 行事企画 & 25. 岩盤力学 & 39. 視聴覚教育 \\
\hline 8. 土木学会誌編集 & 26. 土木計画学研究 & 40. 海外活動 \\
\hline $\begin{array}{l}\text { 9. 土木学会論文集編 } \\
\text { 集 }\end{array}$ & $\begin{array}{l}\text { 27. 海洋開発 } \\
\text { 28. 電算機利用 }\end{array}$ & $\begin{array}{l}\text { 41. 建設コンサルタン } \\
\text { ト }\end{array}$ \\
\hline 10. 文献調查 & 29. 土構造物および基 & 42. 安全問題研究 \\
\hline $\begin{array}{l}\text { 11. 出 版 } \\
\text { 12. 土木工学丵 }\end{array}$ & 30. エネルギー土木 & $\begin{array}{l}\text { 43. 創立 } 70 \text { 周年記念 } \\
\text { 事業 }\end{array}$ \\
\hline 13. 日本土木史研究 & 31. 青函トンネル土圧 & 44. 珢境問題璆談会 \\
\hline 14. 土木製図 & 研究 & 45. 水資源問題穊談会 \\
\hline 15.「新体系土木工学」 & 32. 海上空港連絡調查 & 46. 総合開発懇談会 \\
\hline 編集 & 33. マタディ橋梁技術 & 47. 建設業に関する愳 \\
\hline 16. コンクリート & 34. 鋼鉄道橋設計標準 & 談会 \\
\hline 17. 水 理 & に関する研究 & 48. 土木会館建設㤰談 \\
\hline 18. 鋼構造 & 35. コンクリート鉄道 & 会 \\
\hline
\end{tabular}

手できる.

iv）学会から必要な情報を求めることができない.

v) 自分の職業と無関係な存在である.

表一2 に示されている学会の委員会は, 主として大学 の講座のような編成になっており, 委員の構成比率が学 ・官に片寄っていると共に出版物, 講習会などにはこれ らの委員会で企画されるものがほとんどである.

しかしながら，最近における技術の急速な進歩は，た とえば設計段階における CAD や，施工段階における新 技術の開発, 施工管理手法など，それぞれの段階で体系 的なとらえ方や高度な技術的な手法が用いられるように なった．それにもかかわらず，学会ではこのような流れ に沿うような委員会編成がほとんどなされなかったの で，建設業に所属する技術者のニーズに応えられなかっ たと思われる。

本委員会は, 第 1 期として主として建設業に所属する 会員を委員とする委員会構成で，建設業に所属する技術 者を対象とする事業を行いながらテーマを発掘する.第 2 期では, 学会員の相互協力といら観点で, すべての分 野から委員の参加を願い，施工技術に関する研究を仕上 げるといら方針のもとに運営することにしたいと考えて いる ( (表-3 参照).

表一3 委員会活動のスケジュール

\begin{tabular}{|c|c|c|c|c|}
\hline 項目 昭和 $\cdot$ 年 & 60 & 61 & 62 & 備 考 \\
\hline 第 1 期委貣会編成 & 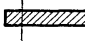 & $\nabla$ & & \\
\hline 第 2 期委員会編成 & & $\mathbb{Z}$ & 4 & \\
\hline 各種事業行事の開催 & שIII & & 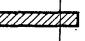 & 年 6 回以上 \\
\hline 研究・報告書の作成 & $E$ & $=-10$ & 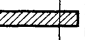 & \\
\hline
\end{tabular}




\section{4. 現在の活動状況}

昭和 59 年 10 月の第 1 回委員会において, 先端技術 の土木分野への適用に関し，官および業界諸団体におけ るそれらの活動とリンクできるような研究活動を行うこ とと, 差当って建設業に属する会員に対するサービスを 行い, 土木学会活動に対して興味をもたせるような事業 を行うことなどが決定された.さらに実務は 40 才前後 の委員からなる小委員会にゆだねることになったので, 運営小委員会を設け, 毎月 1 回づつ会合を開催すること になった. その主な議事内容は表一4に示されている. さらに, 昭和 60 年 4 月より第 1 ～第 4 小委員会を設け (図一2 参照)，委員を増員して業務や行事を分担する ことになった. 昭和 60 年度中における主な行事は次の

\section{表-4 土木施工研究委員会・同運営小委員会活動状況}

\begin{tabular}{|c|c|}
\hline 年月 & 主 \\
\hline $\begin{array}{l}59.10 .30 \\
\text { 第 } 1 \text { 回研究委 }\end{array}$ & $\begin{array}{l}\text { (1)委員紹介. (2)研究委発足主旨確認と運営方針に関一 } \\
\text { 討議. }\end{array}$ \\
\hline $\begin{array}{l}59.10 .30 \\
\text { 第 } 1 \text { 回運営小 }\end{array}$ & $\begin{array}{l}\text { (1)運営小委員会役員選出. (2)建設クレーム } \\
\text { 催方針の討議と PR 方法検討. }\end{array}$ \\
\hline $\begin{array}{l}59.11 .15 \\
\text { 第 } 2 \text { 回運営小 }\end{array}$ & $\begin{array}{l}\text { (1)今後の運営方針討議として, 研究内容の検討, 小委員 } \\
\text { 会の設立とメンハー勧誘, 催物の方針検討を行 } 3 . \text { (2)建 } \\
\text { 設クレームセミナーに関する作業進行状況の検討. }\end{array}$ \\
\hline $\begin{array}{l}59.12 .12 \\
\text { 第 } 3 \text { 回運営小 }\end{array}$ & $\begin{array}{l}\text { (1)建設クレームセミナーの PR 資料, 通訳等の検討, (2) } \\
\text { 最近の施工技術講習会開催計画の立案. (3)第 } 1 \text { 回施工体 } \\
\text { 験発表会開催計画の立案. (4) } 4 \text { 小委員会設立計画とメン } \\
\text { バー勧誘の検討. }\end{array}$ \\
\hline $\begin{array}{l}60.1 .8 \\
\text { 第 } 4 \text { 回運営小 }\end{array}$ & $\begin{array}{l}\text { (1)建設クレームセミナーの出席勧誘方法など検討. (2)最 } \\
\text { 近の施エ技術講習会原稿とテーマの検討. (3)第 } 1 \text { 回施工 } \\
\text { 体験発表会テーマの選定. (4)今後の運営小 (委) の活動 } \\
\text { 方向見直し. }\end{array}$ \\
\hline $\begin{array}{l}60.2 .4 \\
\text { 第 } 5 \text { 回運営小 }\end{array}$ & $\begin{array}{l}\text { (1)建設クレームセミナー参加者集めの詰め. (2) } 9 \text { 月の討 } \\
\text { 論会開催計画の立案. (3)第 } 1 \text { 回施工体験発表会論文原稿 } \\
\text { の検討. (4)最近の施工技術 (講) 進行状況検討. (5)追加 } \\
\text { 委員の確認と } 4 \text { 小委への配置計面. }\end{array}$ \\
\hline $\begin{array}{l}60.3 .4 . \\
\text { 第 } 1 \text { 回合同小 }\end{array}$ & $\begin{array}{l}\text { (1)新メンバーの紹介と第 } 1 \text { 第 } 4 \text { 小（委) の役員選出. } \\
\text { (2)現在までの運営小委員会活動状況説明. }\end{array}$ \\
\hline $\begin{array}{l}60.3 .4 \\
\text { 第 } 6 \text { 回運営小 }\end{array}$ & $\begin{array}{l}\text { (1)建設クレームセミナー開催結果の反省. (2)進行中の催 } \\
\text { 物関連作業状況チェック. }\end{array}$ \\
\hline $\begin{array}{l}60.4 .15 \\
\text { 第 } 7 \text { 回運営小 }\end{array}$ & 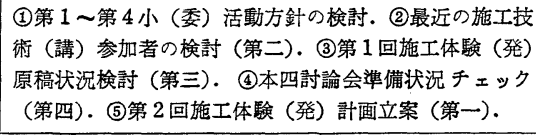 \\
\hline $\begin{array}{l}60.5 .20 \\
\text { 第 } 8 \text { 回運営小 }\end{array}$ & $\begin{array}{l}\text { (1)最近の施工技術 (講) 開催結果の見直し. (2)第 } 1 \text { 回施 } \\
\text { 工体験 (発) 用作業進行状況チェック. (3)本四討論会用 } \\
\text { 作業進行状況検討. (4)第 } 2 \text { 回施工体験発表論文募集要領 } \\
\text { 検討. (5)最近の土木材料 (講) 計画立案. }\end{array}$ \\
\hline $\begin{array}{l}60.5 .27 \\
\text { 第 } 2 \text { 回合同小 }\end{array}$ & $\begin{array}{l}\text { (1)実績報告. } \\
\text { (2)今後の計画. }\end{array}$ \\
\hline $\begin{array}{l}60.6 .27 \\
\text { 第 } 9 \text { 回運営小 }\end{array}$ & $\begin{array}{l}\text { (1)第 } 1 \text { 回施工体験（登) の反省. (2)「海外工事の施工技 } \\
\text { 術」勉強会の会告. (3)第 } 2 \text { 回施工体験（発）の会告. (4) } \\
\text { 委員の追加について. (5昭和 } 61 \text { 年度のスケシュール検 } \\
\text { 討. }\end{array}$ \\
\hline
\end{tabular}

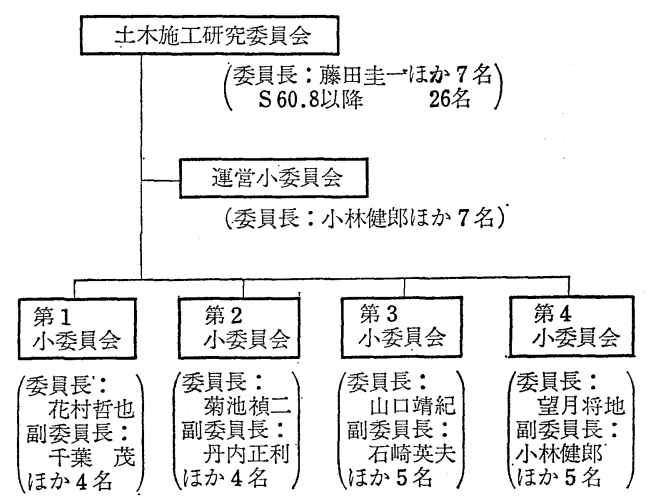

注 : 活動状況に応じ小委員会の数を增減する.

図一2 土木施工研究委員会の組織

表一5 昭和 60 年度中の行事とその予定表

\begin{tabular}{|c|c|c|c|c|}
\hline 行 & 開催日 & 参加者 & 参加費 & 備 考 \\
\hline 建設クレームセミナー & $\begin{array}{l}60 . \\
2.21 \sim 22\end{array}$ & 72 & 48000 & $\begin{array}{l}\text { 米人講師 } \\
2 \text { 名 }\end{array}$ \\
\hline $\begin{array}{l}\text { 最新の施工技術 } 1 \\
\text { 講習会 }\end{array}$ & 4.18 & 153 & $\begin{array}{l}3500 \\
4500^{*}\end{array}$ & 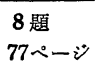 \\
\hline $\begin{array}{c}\text { 第 } 1 \text { 回施工体験発表会 } \\
\text { (マスコンクリート) }\end{array}$ & 6.27 & 144 & $\begin{array}{l}3500 \\
4500^{*}\end{array}$ & $\begin{array}{l}9 \text { 題 } \\
61 \text { ペーシ }\end{array}$ \\
\hline $\begin{array}{l}\text { 第 } 1 \text { 回土木施工技術勉強会 } \\
\text { (海洋土木-本四) }\end{array}$ & 9.27 & & $\begin{array}{l}4800 \\
5800^{*}\end{array}$ & \\
\hline $\begin{array}{l}\text { 第 } 2 \text { 回施工体験発表会 } \\
\text { (海外工事) }\end{array}$ & 11.14 & & & \\
\hline
\end{tabular}

注： * は非会員の参加費

通りである (表一5 参照).

\section{5. 研究活動}

現在の活動状況で述べた行事などに加えて, 研究委員 会としての研究課題に従った活動を 6 月から開始してい る. 研究課題は各種の行事に伴って行うアンケートなど による提案を参考にして決定している. 当面の課題は表 -6 に示されている. なお, 取り上げる研究課題が増加 するに伴って小委員会数と委員数を増加させる予定であ る.

\section{6. 現状の分析}

本委員会によって企画され実施された行事は, 昭和 60 年 6 月現在でまだ 3 件にすぎないが, 学会関係者の当初

\section{表一6 研究課題と分担}

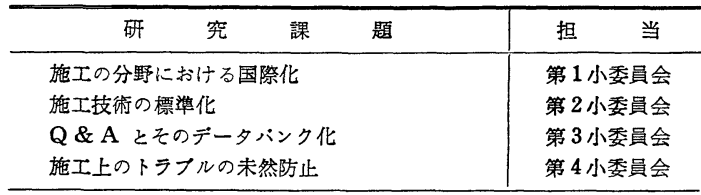


の危惧をよそにして，すべて予想以上の参加者があり， したがって収支は黒字となっている。このまま推移する と委員会に割当てられた予算のすべてを残すだけでな く，学会財政にも貢献できる見通しである。これは今ま でに学会になかった待望の行事であることのほか，委員 全員が参加者の動員にまで気くばりしている成果であろ う.

行事への参加者の内訳をみると, 建設業に属する技術 者がほとんどであるが，学会員の場合でもこれをで学会 行事に出席しなかったか, 出席しても 1 回どまりの人々 が大部分であった. 参加者の半数以上は学会員でない人 々であるが，アンケートの結果により行事に関して興味 をもったことが判明しているので, 今後, 学会への入会 の糸口をつかんだということができよう．学会加入率が 若干向上するだけで，10000人の会員増加も夢でないよ うに思う。

しかし，前述のように，官・学あるいは他分野の民の 会員が委員会に加わっていただけるようになるまでに は，若干の月日が必要である．このような点から，まだ 本委員会は研究委員会としての本来の活動には立ち至っ ていないが，学会の活性化といらことではかなり寄与し ているのではないかと思う.

本委員会の発足直後に，「建設用ロボット委員会」と 「建設マネジメント委員会」が設立され, 施工関係の研 究活動が一層重視される学会の姿勢が打ち出された. 相 互に協力することによって，優れた成果がみのるものと 信ずる.

なお, 会員数が土木学会の約 $1 / 2$ である土質工学会が 主催する学会行事への参加者は, 土木学会の約 1.5 倍 (年次講演会を除く)である.したがって，建設業以外の業 種の分野でも本委員会と同様な企画を進めて活動する余 地は十分残されていると考える.

\section{あとがき}

建設事業の厳しい現状のなかで，建設産業は国内にお いて経営の合理化と新しい技術の開発に取組む一方，国 外に掠いては, 低開発国・開発途上国の基盤整備に協力 する使命感をもって海外市場に出かけている. 海外で は，外国業者とも激しい競争が行われているのであるが 日本の業者が世界の市場で活躍するためには，日本の土 木技術が優れていなければならない。このために，日本 の業者は国内で互いに協力して実力を養うことが必要で あるが，このような場を提供する上で土木学会はふさわ しい位置にある. 本委員会を通じて，各委員はこのよう な使命感をももって非常に良い雾囲気で活動を続けてい ることを報告しておきたい。

本委員会の委員は, 今まで土木学会の委員会活動の経 験がほとんどなかった者が多い。したがって不馿れなた めに，他の委員会や学会事務局の方々にご迷惑をかけた ことがあったかも知れないが，この機会に打許しいただ くようお願いする次第である.

本委員会は，3 年間の活動の成果をみていただいた上 で，その存続の可否を理事会でご判断していただきたい と申上げているが，一日一日が勝負であるという気持で 委員一同は考えている. 本委員会の活動に関して, 会員 諸兄の温かいご理解と絶大なご援助，ご協力ならびにご 意見を賜ることを期待するものである.

なお，本文は運営小委員会の意見に基づいて，委員長 の藤田圭一の責任において作成したものであることを付 記しておく。

\section{$\left.\begin{array}{c}\text { 文責 : 土木施工研究委員会委員長 藤田圭一 } \\ \text { (FUJITA, Keiichi) } \\ \text { 正会員 工博 (株) 間組専務取締役, 技術研究所長 }\end{array}\right)$}

(1985.7.2 • 受付)

\section{ご案内}

論文集第 6 部門編集小委員会では，情報化施工，海外工事，施工システム，施工マネジメント，技術情報，先端 技術，パブリックアクセプタンス（AP)，建設労務，契約・積算，建設諸法，などの土木技術や技術開発の論文を 募集しております。

さらに，上述のほかにも，工事の企画から調查・設計を経ての積算・施工，あるいは検査・補修技術，品質・コ スト・安全・工程などの管理手法や環境・公害対策など，また，新素材や機械に関するもの，そして業際的に発展 する新技術開発とその商品化など一般のニーズに応える業績を幅広く募集しております. 